\title{
EFFECTS OF INCREASING ACYLATION AND ENZYMATIC HYDROLYSIS ON FUNCTIONAL PROPERTIES OF BAMBARA BEAN (VIGNA SUBTERRANEA) PROTEIN CONCENTRATE
}

\author{
M. Mune MunE ${ }^{a *}$, S. MinkA ${ }^{b}$ and I. MBomE ${ }^{c}$ \\ ${ }^{a}$ The Higher Institute of Sahel, University of Maroua, PO Box 46 Maroua. Cameroon \\ ${ }^{\mathrm{b}}$ Department of Biochemistry, University of Yaounde I, PO Box 812 Yaounde. Cameroon \\ ${ }^{\mathrm{c}}$ Food and Nutrition Research Centre, PO Box 6163 Yaounde. Cameroon
}

(Received: 22 September 2012; accepted: 28 January 2013)

\begin{abstract}
Bambara bean protein concentrate was acylated and partially hydrolysed with pancreatin in order to improve its functional properties. Increasing acetylation and succinylation (from 0.0 to $1.0 \mathrm{~g}$ anhydride/g concentrate) modified lysine at similar rate. Acylation markedly improved protein solubility and water solubility index at neutral $\mathrm{pH}$, which reached to 92 and $94 \%$, respectively. Acetylation showed greater effect on emulsifying activity, which was maximum at $0.5 \mathrm{~g}$ anhydride/g concentrate, and emulsifying stability was higher at $0.25 \mathrm{~g}$ anhydride/g concentrate. A significant increase in foam capacity was recorded at $0.5 \mathrm{~g}$ succinic anhydride/g concentrate, and foam stability decreased detrimentally following acylation. Fat absorption capacity was not improved by acylation. At $\mathrm{pH} 3.5$, protein solubility of acylated concentrate was low $(<14 \%)$. Hydrolysis of protein concentrate with pancreatin resulted in significant increase in protein solubility at neutral $\mathrm{pH}$. At isoelectric $\mathrm{pH}$, solubility of protein hydrolysates increased with the increasing degree of hydrolysis.
\end{abstract}

Keywords: Bambara bean, protein concentrate, functional properties, acylation, enzymatic hydrolysis

Many food and non-food industries need low-cost protein ingredients with good nutritional and functional properties for use in various formulations. This need is particularly important in developing and under-developed countries where the supply of proteins of animal origin is limited due to unavailability and high price. Many grain legumes widely cultivated throughout Africa, Asia and America, such as Bambara bean or cowpea (DOKU \& KARIKARI, 1971), are known to have high protein content with good nutritional value and functional properties. In addition, techniques employed during protein extraction from grain legumes contribute to the elimination of antinutritional factors. Unfortunately, native proteins possess limited functionality, and the protein extraction procedure can alter the existing functional properties. In this regard, physical, chemical and enzymatic modifications are often performed to expand the range of functional properties available.

Acylation with acetic and succinic anhydrides is the most widely employed chemical modification to improve some functional properties of food proteins. The observed changes in functionality have been related to alteration in protein structure including protein denaturation, partial unfolding, altered isoelectric point, decrease of the enthalpy of denaturation and increase in hydrophobicity (ACHOURI \& ZHANG, 2001). Acylated proteins remain capable of precipitation phenomenon due to their high molecular weight. This complicates their utilization in foodstuffs of moderate acidity, such as citric beverages and dressings, especially when the required functional properties depend on solubility (WALSTRA,

\footnotetext{
* To whom correspondence should be addressed.

Phone: +237 99309667; e-mail: alainmune@yahoo.fr
} 
1989). In this regard, partial hydrolysis of proteins with proteases is used to improve their functional properties, particularly solubility over a wide $\mathrm{pH}$ range (PANYAM \& KILARA, 1996). There is an increasing demand for protein hydrolysates for commercial applications, like a number of formulated diets that are suitable for geriatrics, high-energy supplements or hypoallergenic infant formulas.

The purpose of this work was to evaluate the effect of progressive acetylation and succinylation on the functional properties of Bambara bean protein concentrate prepared under optimum conditions (MunE MunE et al., 2010), and improve solubility at the isoelectric $\mathrm{pH}(\mathrm{pH} 4.5)$ by partial hydrolysis with pancreatin.

\subsection{Materials}

\section{Materials and methods}

Bambara bean (Vigna subterranea) seeds were purchased from Mokolo market (Yaoundé, Cameroon). The seeds were hand-picked and stored in polyethylene bags in the refrigerator $\left(\sim{ }^{\circ} \mathrm{C}\right)$ until used.

\subsection{Methods}

1.2.1. Preparation of Bambara bean flour. Bambara bean seeds were washed and rinsed in deionised water at room temperature $\left(25 \pm 2{ }^{\circ} \mathrm{C}\right)$. They were dried in an air convection oven at $50{ }^{\circ} \mathrm{C}$ for $72 \mathrm{~h}$, then cracked and dehulled. The dried seeds were ground into flour, passed through a $150 \mu \mathrm{m}$ mesh sieve, stored hermetically in polyethylene bag in a refrigerator at approximately $4{ }^{\circ} \mathrm{C}$.

1.2.2. Preparation of Bambara bean protein concentrate. Bambara bean protein concentrate was prepared by the isoelectric precipitation method as described by MUNE MUNE and co-workers (2010). The concentrate contained $70.85 \%$ protein determined according to the A.O.A.C. (1990) method.

1.2.3. Acylation of Bambara bean protein concentrate. Bambara bean protein concentrate $(10 \%, \mathrm{w} / \mathrm{v})$ was homogenised in $0.1 \mathrm{M}$ carbonate buffer $\mathrm{pH} 8.3$, for $3 \mathrm{~h}$ at room temperature $\left(25 \pm 2{ }^{\circ} \mathrm{C}\right)$. Succinic or acetic anhydrides (Merck, Germany) was added in small increments with constant stirring over 30-60 min at the levels of $0.25,0.50,0.75$ and $1.00 \mathrm{~g}$ anhydride/g concentrate in the slurry. During the reaction, the $\mathrm{pH}$ was maintained between 8.0 and 8.5 with $2.5 \mathrm{M} \mathrm{NaOH}$. After the $\mathrm{pH}$ stabilized, the suspensions were left for $2 \mathrm{~h}$ at room temperature and then dialyzed against deionised water for $48 \mathrm{~h}$ at $4{ }^{\circ} \mathrm{C}$ to remove excess anhydride, then freeze-dried in a Freezone 6 (Labconco, Kansas City, MO, USA) freezedryer. A control was prepared in the same manner without adding anhydrides.

The extent of acylation was estimated by determining the available lysine content of the protein according to HURRELL and co-workers (1979), using 1-phenylazo-2-naphtol-6sulphonic acid (Orange 12). Modification was expressed as percent reduction in the available lysine residues. The crude protein $(\mathrm{N} \times 6.25)$ and moisture contents were determined according to A.O.A.C. (1990) methods. 
1.2.4. Enzymatic hydrolysis with pancreatin. The proteolysis was performed based on the method of Kong and co-workers (2006). Bambara bean protein concentrate (20 g) was mixed with $190 \mathrm{ml}$ of a $0.1 \mathrm{M}$ phosphate buffer $\mathrm{pH} 8.5$ and the $\mathrm{pH}$ of the mixture was adjusted to 8.5 using $2 \mathrm{M} \mathrm{NaOH}$, and the mixture was stirred for $2 \mathrm{~h}$ at room temperature $\left(25 \pm 2{ }^{\circ} \mathrm{C}\right.$ ). The mixture was preincubated at $37^{\circ} \mathrm{C}$ for $30 \mathrm{~min}$, then $10 \mathrm{ml}$ of a pancreatin (4 usp, SIGMA) solution of $3.9 \mathrm{mg} \mathrm{ml}^{-1}$ in phosphate buffer was added to obtain a final enzyme/ substrate ratio of $3 \%(\mathrm{w} / \mathrm{w})$. The reaction was allowed to proceed under constant stirring at $37^{\circ} \mathrm{C}$ for 50 to $300 \mathrm{~min}$, and the $\mathrm{pH}$ was maintained at 8.5 by the addition of $1 \mathrm{M} \mathrm{NaOH}$. After each 50-min reaction interval, the $\mathrm{pH}$ of the mixture was adjusted to 7.0 with $2.5 \mathrm{M}$ $\mathrm{HCl}$, and the reaction was stopped by heating at $100{ }^{\circ} \mathrm{C}$ for $10 \mathrm{~min}$, then cooled in an ice bath at $4{ }^{\circ} \mathrm{C}$. The protein hydrolysates obtained were freeze-dried and stored at $4{ }^{\circ} \mathrm{C}$. A control was prepared in the same manner, with the pancreatin solution replaced by the $0.1 \mathrm{M}$ phosphate buffer $\mathrm{pH} 8.5$, and the mixture was incubated for $300 \mathrm{~min}$ at $37^{\circ} \mathrm{C}$.

The degree of hydrolysis (DH) was calculated as the percentage of $10 \%$ TCA-soluble nitrogen to total nitrogen in the sample, as described by Drago and Gonzalez (2001). Determination of nitrogen content was performed by Kjeldahl method (A.O.A.C., 1990).

1.2.5. Functional properties. 1.2.5.1. Nitrogen solubility index. Nitrogen solubility index was determined based on the method of BorA (2002). Freeze-dried samples (1 g) were suspended in $100 \mathrm{ml}$ of $0.1 \mathrm{M}$ acetate buffers at various pHs: $\mathrm{pH} 3.5-4.5$ and in $0.1 \mathrm{M}$ phosphate buffer at $\mathrm{pH}$ 7. The suspensions were agitated with a magnetic stirrer for $3 \mathrm{~h}$ at room temperature, the $\mathrm{pH}$ was checked and if necessary adjusted, then centrifuged at $2000 \mathrm{~g}$ for $30 \mathrm{~min}$. The supernatants were analysed for nitrogen content by the Kjeldahl method (A.O.A.C., 1990), and the percentage of soluble nitrogen was calculated at each $\mathrm{pH}$ value.

1.2.5.2. Water solubility index. Water solubility index (WSI) was determined based on the method of ANDERSON and co-workers (1969). A weight of $0.2 \mathrm{~g}$ (M0) of freeze-dried samples was suspended in $20 \mathrm{ml}$ of $0.1 \mathrm{M}$ acetate buffers at various pHs: $\mathrm{pH} 3.5-4.5$ and in $0.1 \mathrm{M}$ phosphate buffer at $\mathrm{pH} 7$. The suspensions were agitated for $30 \mathrm{~min}$ at room temperature, the $\mathrm{pH}$ was checked and if necessary adjusted, then centrifuged at 5000 r.p.m. for $30 \mathrm{~min}$. The resulting sediment was weighed and then dried at $105^{\circ} \mathrm{C}$ for $24 \mathrm{~h}$ and the dried weight (M1) was determined. The WSI was calculated as follows:

$$
\mathrm{WSI}=(\mathrm{M} 0-\mathrm{M} 1) \times 100 / \mathrm{M} 0
$$

1.2.5.3. Oil absorption capacity. Oil absorption capacity was determined by vortex mixing $0.1 \mathrm{~g}$ of freeze-dried sample and $10 \mathrm{ml}$ of vegetable oil (Mayor, SCR Maya \& Cie, Douala, Cameroon) of density $=0.877( \pm 0.002) \mathrm{g} \mathrm{ml}^{-1}$ for $1 \mathrm{~min}$ and allowing to stand for 30 $\mathrm{min}$ at room temperature. The mixture was centrifuged (at $2000 \mathrm{~g}$ for $30 \mathrm{~min}$ at $25^{\circ} \mathrm{C}$ ) and the weight of the supernatant was obtained. The volume $(\mathrm{ml})$ of oil absorbed per $\mathrm{g}$ of sample on a dry weight basis was recorded as oil absorption capacity.

1.2.5.4. Emulsifying properties. Emulsifying activity (EA) and emulsifying stability index (ESI) were measured based on the method described by PEARCE and Kinsella (1978). To the freeze-dried sample dispersions $(1 \%$; w $/ \mathrm{v}, 7.5 \mathrm{ml})$ in $0.1 \mathrm{M}$ phosphate buffer of $\mathrm{pH} 7$, $2.5 \mathrm{ml}$ of vegetable oil was added. The mixtures were then homogenized for $1 \mathrm{~min}$ at 1400 r.p.m. using an Agimatic-S (Selecta, Barcelona) agitator. Afterwards, a $50 \mu 1$ volume of the 
emulsion formed was immediately taken from the bottom of the container, and diluted in 10 $\mathrm{ml}$ of the same buffer containing $0.1 \%$ (w/v) of sodium dodecyl sulphate (SDS). Absorbance of the diluted sample was measured at $500 \mathrm{~nm}$ at $0 \mathrm{~min}$ (A0) and $10 \mathrm{~min}$ (A10). Absorbance at 0 min was recorded as EA. The ESI was calculated as follows:

$$
\mathrm{ESI}(\min )=\mathrm{A} 0 \times 10 /(\mathrm{A} 0-\mathrm{A} 10)
$$

1.2.5.5. Foaming properties. Foam capacity (FC) and foam stability (FS) were assessed based on the method of LAWHON and co-workers (1972). The freeze-dried samples $(1 \%, \mathrm{w} / \mathrm{v})$ in $0.1 \mathrm{M}$ phosphate buffer at $\mathrm{pH} 7$ were mixed thoroughly at 1400 r.p.m. for $1 \mathrm{~min}$ in a graduate cylinder. The percentage increase in foam was recorded as FC. FS was estimated as the percentage of foam remaining after 20,40 and $60 \mathrm{~min}$ of standing at room temperature.

1.2.6. Statistical analysis. All experiments were replicated at least 3 times. Mean values with standard deviations were reported. The data were analysed by the Student-NewmanKeuls test. Correlation was estimated by the method of Pearson. The computer software used in this study were SPSS (version 10.1, 2000, SPSS Inc., USA) and STATISTICA (version 5.5, 2002; Statsoft Inc., USA).

\section{Results and discussion}

\subsection{Extent of acylation}

Generally, all nucleophilic groups of the amino acid residues, such as sulfhydryl, phenol, imidazole, hydroxyl and $\varepsilon$-amino groups can be acylated. However, the extent of $\mathrm{N}$-acylation was predominant because of the low $\mathrm{pK}$ and less steric hindrance of the $\varepsilon$-amino group. The extent of acylation of Bambara bean protein concentrate increased with the increasing concentration of acetic or succinic anhydride. No significant $(\mathrm{P}<0.05)$ difference was found at the same acetic and succinic anhydride levels. Acylation increased sharply at the ratio of $0.25 \mathrm{~g}$ anhydride/g concentrate (80\%), then smoothly at the following anhydride concentrations. These results suggested that most of the $\varepsilon$-amino groups of lysine were accessible for anhydride at $\mathrm{pH}$ 8-8.5. Moreover, the initial acylation of exposed amino residues may have altered the protein conformation and enhanced the availability of otherwise inaccessible lysine groups.

\subsection{Protein solubility and water solubility index}

Protein solubility increased with the concentration of acetic anhydride, up to the maximum (88\%) at $0.50-0.75 \mathrm{~g}$ anhydride/g concentrate, then decreased at $1.0 \mathrm{~g} \mathrm{~g}^{-1}$ (Fig. 1A). Succinylation produced the higher protein solubility $(80 \%)$ at the concentration of $0.75 \mathrm{~g} \mathrm{~g}^{-1}$ (Fig. 1A). This improvement reflects increase in the net negative charge of protein, which reduces protein-protein interaction and increases protein-water interaction. In addition, acylation promotes protein dissociation and changes in tertiary structure, particularly polypeptide unfolding (Gruener \& Ismond, 1997; Achouri \& Zhang, 2001). Decrease in protein solubility at high levels of acetylation at neutral $\mathrm{pH}$ was observed for mung bean protein isolate (EL-ADAWY, 2000). High levels of acetylation promote protein aggregation, formed by hydrophobic bonds between alkyl and aromatic groups in constituent amino acid 
residues. Also, protein unfolding due to intramolecular electrostatic repulsive forces between the succinate carboxyl groups and the neighbouring native carboxyl groups can expose buried hydrophobic amino acid residues (KRASAECHOL et al., 2008), which results in decrease of protein solubility. ACHOURI and ZHANG (2001) showed that surface hydrophobicity of soy protein increases at high level of succinylation. Protein solubility was positively correlated to water solubility index $(\mathrm{r}=0.92 ; \mathrm{P}<0.05)$. The maximum WSI $(97 \%)$ was obtained at $0.75 \mathrm{~g}$ succinic or acetic anhydride/g concentrate (Fig. 1B). Changes on conformation and net negative charge following acylation probably affected protein interaction with non-protein constituents, such as lipids and carbohydrates.

Acylated (acetylated and succinylated) legume proteins with high molecular weight remained capable of forming insoluble aggregates at acidic $\mathrm{pH}$. The resulting low solubility in acidic media complicates their use in foodstuffs of moderate acidity. Due to increase in their negative charge, the $\mathrm{pH}$ of minimum solubility of acylated proteins shifted toward the acidity, generally from 0.5 to 1.0 unit (ACHOURI et al., 1998). The maximum protein solubility $(13.90 \%)$ was obtained at 0.75 and $1.0 \mathrm{~g}$ succinic anhydride/g concentrate (Fig. 1C). This value was lower $(\mathrm{P}<0.05)$ than those of the acylated concentrate at $\mathrm{pH} 7$.

\subsection{Oil absorption capacity}

Oil absorption capacity (OAC) of acylated Bambara bean protein concentrate was not significantly $(\mathrm{P}>0.05)$ different from that of the untreated protein concentrate $\left(3.4 \mathrm{ml} \mathrm{g} \mathrm{g}^{-1}\right)$. $\mathrm{OAC}$ depends on a number of factors including the protein content, the degree of dissociation of oligomers and unfolding of polypeptides, which affect the physical entrapment of oil, exposure of more hydrophobic groups for interaction with oil, the charge and topography of protein molecules (EL-ADAWY, 2000).

\subsection{Emulsifying properties}

Acetylation significantly $(\mathrm{P}<0.05)$ improved EA compared to untreated Bambara bean concentrate. Furthermore, the acetylated concentrate showed better EA than succinylated one, at all anhydride concentrations (Table 1). EA increased with increasing acetic anhydride concentration, reached the maximum (1.11) at $0.5 \mathrm{~g}$ anhydride/g concentrate, then decreased thereafter. The highest EA of succinylated concentrate was noted at the anhydride concentration of $1.0 \mathrm{~g} \mathrm{~g} \mathrm{~g}^{-1}$. ESI of Bambara bean protein concentrate was markedly improved at the anhydride concentration of $0.25 \mathrm{~g} \mathrm{~g}^{-1}$, and was 13.39 and $15.38 \mathrm{~min}$, for acetylated and succinylated concentrates, respectively (Table 1). Generally, solubility, surface hydrophobicity and molecular flexibility influenced the emulsifying behaviour of globular proteins. Increase in EA following acylation may be a reflection of the increased solubility. Good solubility promoted rapid diffusion of protein molecules to the oil-water interface and the formation of an elastic layer around the fat droplets, which retarded coalescence. In this respect, EA of acetylated Bambara bean concentrate was significantly correlated $(\mathrm{r}=0.928 ; \mathrm{P}<0.05)$ to protein solubility. Decrease in emulsifying properties following acylation may be attributed to the increase in the net negative charge, which reduces protein-protein interaction and prevents the formation of an elastic film at the interface. Similar results were reported by ELADAWY (2000) for mung bean protein isolate. 
A

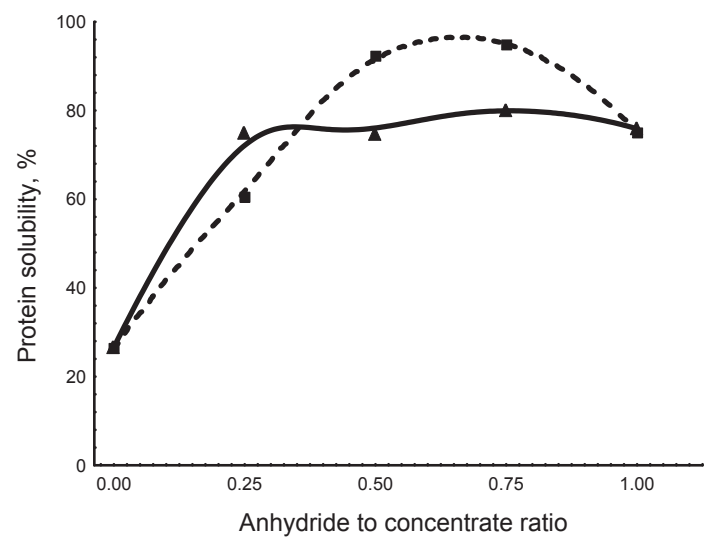

B

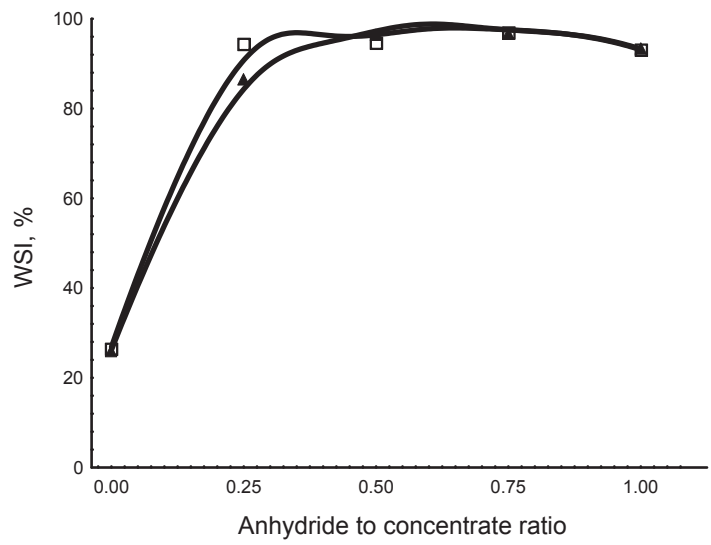

C

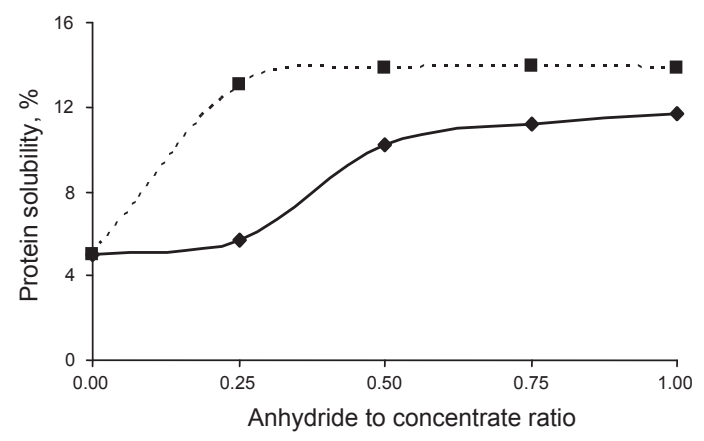

Fig. 1. Effect of various concentrations of acetic and succinic anhydride on (A) protein solubility at $\mathrm{pH} 7$, $\mathbf{\Delta}$ : succinylation; acetylation; (B) water solubility index (WSI) at $\mathrm{pH} 7, \square$ : succinylation; $\mathbf{\Delta}$ : acetylation and (C) protein solubility at $\mathrm{pH} 3.5$ of Bambara bean protein concentrate, $\$$ : succinylation; acetylation 
Table 1. Effect of various concentrations of acetic and succinic anhydride on the emulsifying activity (EA) and emulsifying stability index (ESI) of Bambara bean protein concentrate*

\begin{tabular}{lccc}
\hline & g Anhydride/g concentrate & EA & ESI (min) \\
\hline \multirow{3}{*}{ Acetic anhydride } & 0.00 & $0.334 \mathrm{a}$ & $10.367 \mathrm{a}$ \\
& 0.25 & $0.701 \mathrm{c}$ & $13.386 \mathrm{c}$ \\
& 0.50 & $1.111 \mathrm{~g}$ & $11.514 \mathrm{ab}$ \\
& 0.75 & $1.032 \mathrm{f}$ & $11.298 \mathrm{ab}$ \\
Succinic anhydride & 1.00 & $0.613 \mathrm{~d}$ & $12.297 \mathrm{bc}$ \\
& 0.25 & $0.364 \mathrm{ab}$ & $15.382 \mathrm{~d}$ \\
& 0.50 & $0.361 \mathrm{~b}$ & $12.977 \mathrm{bc}$ \\
& 0.75 & $0.344 \mathrm{ab}$ & $13.618 \mathrm{c}$ \\
& 1.00 & $0.403 \mathrm{c}$ & $13.546 \mathrm{c}$ \\
\hline
\end{tabular}

${ }^{*}$ Means in the same column with different letters are significantly different $(\mathrm{P}<0.05)$

\subsection{Foaming properties}

Foam capacity (FC) of untreated Bambara bean protein concentrate was 40\% (Table 2). Acetylation and succinylation of Bambara bean concentrate decreased FC, except at the concentration of $0.5 \mathrm{~g}$ succinic anhydride/g concentrate, compared to the untreated concentrate. Low foam capacity could be the reflection of presence of lipids in Bambara bean protein concentrate, combined to the increased charge density of acylated protein, which inhibits the protein-protein interaction at the air-water interface (LAWAL et al., 2005).

Acylation markedly decrease foam stability of Bambara bean concentrate between 20 and $60 \mathrm{~min}$, compared to the untreated concentrate (Table 2). This decrease in FS was the result of the increased charge density of the acylated protein.

\subsection{Enzymatic hydrolysis}

The extent of enzymatic hydrolysis of Bambara bean protein concentrate with pancreatin is quantified as the degree of hydrolysis (DH), which refers to the number of peptide bonds cleaved. The proteolysis was monitored for $300 \mathrm{~min}$ by the $\mathrm{DH}$, and the resulting curve is shown in Fig. 2. The DH versus hydrolysis time curve was hyperbolic, and well fitted by the model $\mathrm{Y}=\mathrm{ax} / \mathrm{b}+\mathrm{x}$, where $\mathrm{y}$ represents the $\mathrm{DH}$; $\mathrm{x}$ is hydrolysis time, $\mathrm{a}$ and $\mathrm{b}$ are constants ( $a=25.62 \pm 0.44$ and $b=6.97 \pm 2.03$ ). The fitted model accounted for more than $99.83 \%$ of the variation in the experimental data. The proteolysis proceeded at a rapid rate during the initial $100 \mathrm{~min}$, and then slowed down. The DH reached $23.46 \%$ after $100 \mathrm{~min}$ of incubation, then 24.62 and $25.58 \%$ after 200 and $300 \mathrm{~min}$, respectively. The reasons for the decrease of rate of hydrolysis mainly include the decrease in specific peptide bonds available for enzyme action, enzyme inactivation and competition between the native protein and the peptides being formed during hydrolysis (GUAN et al., 2006). Similar results were obtained for hydrolysis of wheat gluten with trypsin, pancreatin and alcalase (KonG et al., 2006), and hemp protein isolate with trypsin (YIN et al., 2008). PANYAM and KILARA (1996) reported that the decrease in molecular weight, which accompanied the enzymatic hydrolysis of proteins, was a major effect, which contributed to the improvement in the functional properties of protein hydrolysates. 
Table 2. Effect of various concentrations of acetic and succinic anhydride on the foam capacity (FC) and foam stability (FS) of Bambara bean protein concentrate*

\begin{tabular}{lccccc}
\hline & $\begin{array}{c}\text { Concentration } \\
(\mathrm{g} \mathrm{g}-1)\end{array}$ & FC (\%) & & FS (\%) \\
\cline { 4 - 6 } & & & $20 \mathrm{~min}$ & $40 \mathrm{~min}$ & $60 \mathrm{~min}$ \\
\hline \multirow{3}{*}{ Acetic anhydride } & 0.00 & $40.00 \mathrm{e}$ & $32.00 \mathrm{~d}$ & $30.00 \mathrm{c}$ & $24.00 \mathrm{c}$ \\
& 0.25 & $31.25 \mathrm{~d}$ & $10.42 \mathrm{c}$ & $2.08 \mathrm{a}$ & $2.08 \mathrm{a}$ \\
& 0.50 & $29.17 \mathrm{c}$ & $2.08 \mathrm{a}$ & $0.00 \mathrm{a}$ & $0.00 \mathrm{a}$ \\
& 0.75 & $27.08 \mathrm{~b}$ & $2.08 \mathrm{a}$ & $0.00 \mathrm{a}$ & $0.00 \mathrm{a}$ \\
Succinic anhydride & 1.00 & $17.20 \mathrm{a}$ & $0.00 \mathrm{a}$ & $0.00 \mathrm{a}$ & $0.00 \mathrm{a}$ \\
& 0.25 & $32.10 \mathrm{~d}$ & $4.94 \mathrm{~b}$ & $2.47 \mathrm{a}$ & $0.00 \mathrm{a}$ \\
& 0.50 & $55.88 \mathrm{f}$ & $8.32 \mathrm{c}$ & $1.47 \mathrm{a}$ & $1.47 \mathrm{a}$ \\
& 0.75 & $32.10 \mathrm{~d}$ & $4.94 \mathrm{~b}$ & $2.47 \mathrm{a}$ & $0.00 \mathrm{a}$ \\
& 1.00 & $32.10 \mathrm{~d}$ & $9.88 \mathrm{c}$ & $4.94 \mathrm{~b}$ & $4.94 \mathrm{~b}$ \\
\hline
\end{tabular}

*Means in the same column with different letters are significantly different $(\mathrm{P}<0.05)$

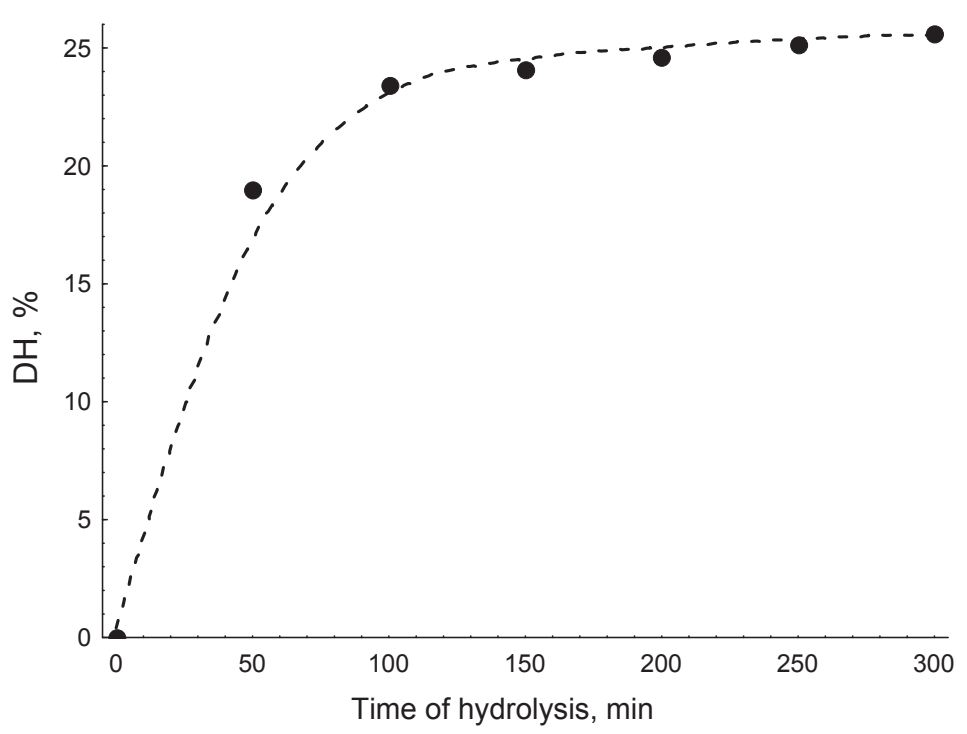

Fig. 2. Effect of the duration of enzymatic hydrolysis on the degree of hydrolysis (DH) of Bambara bean protein concentrate

\subsection{Solubility of Bambara bean protein hydrolysates}

Solubility is one of the most important functional properties of proteins, since it can affect other functional properties, such as surface active, rheological, or hydrodynamic properties. Good solubility of proteins is usually required in many functional applications, especially for emulsions, foams, and gels. Solubility of Bambara bean protein hydrolysates as a function of $\mathrm{DH}$, at $\mathrm{pH} 7$ and 4.5, is presented in Fig. 3. Bambara bean protein hydrolysates showed 
significantly $(\mathrm{P}<0.05)$ higher solubility than the untreated control $(\mathrm{DH} 0 \%)$ at $\mathrm{pH} 7$ and 4.5 . At $\mathrm{pH} 7$, the protein solubility was constant for DH between 18.82 and $25.12 \%$ at $77 \%$, then decreased for DH $25.58 \%$ at $71 \%$. Increase in protein solubility following the enzymatic hydrolysis of hemp protein isolate by trypsin was reported by YIN and co-workers (2008). The improvement in the solubility of Bambara bean protein hydrolysates was probably due to the smaller size of peptides, and the corresponding increase in the number of exposed ionisable amino and carboxyl groups (PANYAM \& KILARA, 1996). In addition, partial proteolysis could promote the exposition of buried hydrophobic groups of amino acid residues, resulting in the alteration of protein interaction with water.

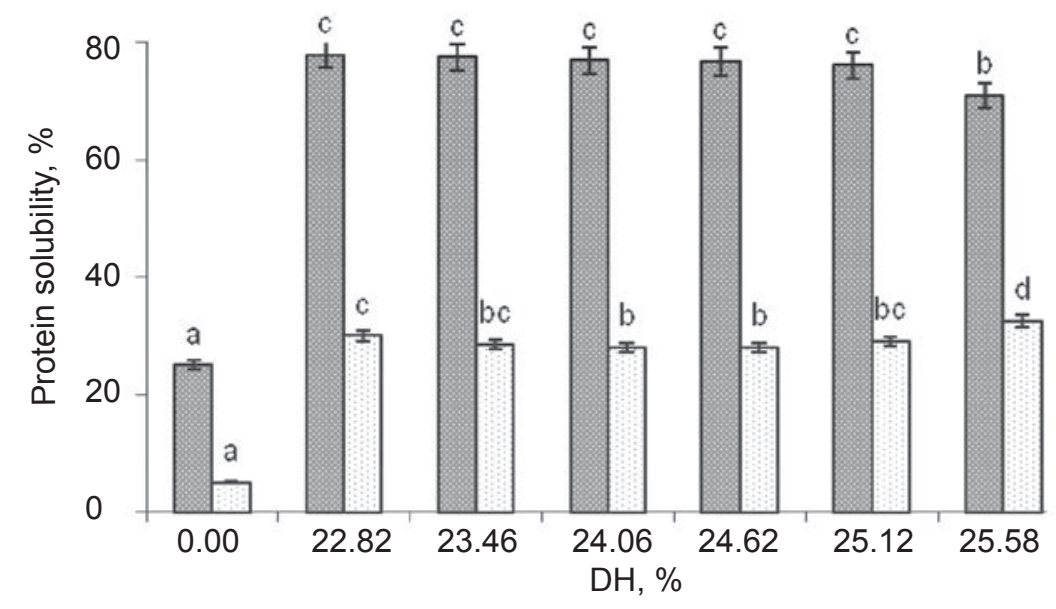

Fig. 3. Effect of the degree of hydrolysis (DH) on the solubility of Bambara bean protein hydrolysates at $\mathrm{pH} 7$ and 4.5. Values followed by different letters are significantly $(\mathrm{P}<0.05)$ different.

$\square: \mathrm{pH} 7.0 ; \square: \mathrm{pH} 4.5$

At $\mathrm{pH} 4.5$ (isoelectric $\mathrm{pH}$ ), the maximum solubility of Bambara bean protein hydrolysates was noted for $\mathrm{DH}$ of $25.58 \%$ at $32.51 \%$. The increment in solubility at $\mathrm{pH} 4.5$ could be mainly ascribed to the liberation of peptides of low molecular weight, since solubility was positively correlated to $\mathrm{DH}(\mathrm{r}=0.987 ; \mathrm{P}<0.01)$. Thus, limited enzymatic hydrolysis can be used as an effective technique to improve protein solubility of Bambara bean protein concentrate, over a wide $\mathrm{pH}$ range.

\section{Conclusions}

In summary, acylation of Bambara bean protein concentrate is an effective mean to enhance functional properties at neutral $\mathrm{pH}$, particularly for solubility, emulsifying properties and foam capacity. However, an insignificant change in fat absorption capacity of Bambara bean concentrate was noted following acylation, and a detrimental decrease in foam stability was observed. Use of acetylated Bambara bean protein concentrate in acid beverages is complicated due to their low solubility at $\mathrm{pH} 3.5$. Partial hydrolysis with pancreatin improved the solubility of the protein concentrate at neutral $\mathrm{pH}$. At isoelectric $\mathrm{pH}$, Bambara bean 
protein hydrolysate was 2 to 3 times more soluble than the acylated concentrate. Modified Bambara bean protein concentrate can then be used as a cheap functional ingredient for food formulations in developing and under developed countries.

This work was done with the resources of the Food and Nutrition Research Centre (IMPM), Ministry of Scientific Research and Innovation, Yaoundé Cameroon.

\section{References}

Achouri, A. \& Zhang, W. (2001): Effect of succinylation on the physicochemical properties of soy protein hydrolysates. Fd Res. Int., 34, 507-514.

Achouri, A., Zhang, W. \& ShiYing, X. (1998): Enzymatic hydrolysis of soy protein isolate and effect of succinylation on the functional properties of resulting protein hydrolysates. Fd Res. Int., 31, 617-623.

Anderson, R.A., Convay, H.F., Pfeifer, V.F. \& Griffin, E.L. (1969): Roll and extrusion cooking of grain sorghum grits. Cereal Sci. Today, 14, 372-375.

A.O.A.C. (1990): Official methods of analysis. (15th ed.) Method 970.87. Association of Official Analytical Chemists, Arlington

BorA, P.S. (2002): Functional properties of native and succinylated lentil (Lens culinaris) globulins. Fd Chem., 77, $171-176$

Doku, E.V. \& KariKaRI, S.K. (1971): Bambara groundnut. Ecol. Bot., 25, 225-262.

Drago, S.R. \& Gonzalez, R.J. (2001): Foaming properties of enzymatically hydrolysed wheat gluten. Innov. Fd Sci. Emerg. Technol., 1, 269-273.

EL-ADAWY, T.A. (2000): Functional properties and nutritional quality of acetylated and succinylated mung bean protein isolate. Fd Chem., 70, 83-91.

Gruener, L. \& IsMOND, M.A.H. (1997): Effects of acetylation and succinylation on the physicochemical properties of the canola 12S globulin. Part I. Fd Chem., 60, 513-520.

Guan, X., Yao, H., Chen, Z., Shan, L. \& Zhang, M. (2006): Some functional properties of oat bran protein concentrate modified by trypsin. Fd Chem., 101, 163-170.

Hurrell, R.F., Lerman, P. \& Carpenter, K.J. (1979): Reactive lysine in foodstuffs as measured by a rapid dye binding procedure. J. Fd Sci., 44, 1221-1227.

KonG, X., ZHOU, H. \& Qian, H. (2006): Enzymatic preparation and functional properties of wheat gluten hydrolysates. Fd Chem., 101, 615-620.

Krasaechol, N., Sanguandeekul, R., Duangmal, K. \& Owusuapenten, R.K. (2008): Structure and functional properties of modified threadfin bream sarcoplasmic protein. Fd Chem., 107, 1-10.

Lawal, O.S., Adebowale, K.O., Ogunsanwo, B.M., Sosanwo, O.A. \& Bankole, S.A. (2005): On the functional properties of globulin and albumin protein fractions and flours of African locust bean (Parkia biglobossa). Fd Chem., 92, 681-691.

Lawhon, J.T., Rooney, L., CARTer, C.M. \& MatTi, K.F. (1972): A comparative study of the whipping potential of an extract from several oilseed flours. Cereal Sci. Today, 17, 240-243.

Mune Mune, M.A., Mвome, L.I. \& Minka, S.R. (2010): Optimization of protein concentrate preparation from Bambara bean using response surface methodology. J. Fd Process Engng, 33, 398-412.

Panyam, D. \& Kilara, A. (1996): Enhancing the functionality of food proteins by enzymatic modification. Trends Fd Sci. Technol., 7, 120-125.

Pearce, K.N. \& Kinsella, J.E. (1978): Emulsifying properties of proteins: evaluation of a turbidimetric technique. J. Agric. Fd Chem., 26, 716-723.

Walstra, P. (1989): Principles of foam formation and stability. -in: WiLson, A.J. (Ed.), Foam, physics, chemistry and structure. Springer-Verlag, London, pp. 1-15.

Yin, S.W., Tang, C.H., CAO, J.S., Hub, E.K., Wen, Q.B. \& YanG, X.Q. (2008): Effects of limited enzymatic hydrolysis with trypsin on the functional properties of hemp (Cannabis sativa L.) protein isolate. Fd Chem., 106, 1004-1013. 